\section{HORIZONS OF RAILWAY TRANSPORT 2012}

\section{Globalization trends and their impact on the trans-} port system in terms of the EU common market

The international scientific Conference Horizons of Railway Transport 2012 was held on 13 and 14 September 2012 in Strečno, the Slovak Republic, under the title "Globalization trends and their impact on the transport system in terms of the EU common market". The Conference took place at the Central Training and Psychology Institute of Railways of Slovak Republic (ŽSR). The Conference organizer was the University of Žilina supported by the Ministry of Transport, Construction and Regional development of the Slovak Republic, Railways of Slovak Republic (ŽSR), Železničná spoločnost' Slovensko, a.s. (ZSSK), Železničná spoločnost' Cargo Slovakia, a.s. (ZSSK CARGO) and Slovak Scientific and Technical Society Transport (SVTS - D).

The Conference gathered distinguished scientists and practitioners from the sector of railway traffic. The scientists arrived from the Slovak Republic, the Czech Republic, Austria, Lithuania, Russia, Hungary, Bulgaria, Poland, and Croatia.

In the introductory part of the Conference the audience was first addressed by Prof. Tatiana Čorejova, Ph.D., Rector of the University of Žilina, and she reminded in the beginning about the soon coming nextyear $60^{\text {th }}$ anniversary of the University of Žilina, and emphasised the importance of the scientific conferences in the field of research in railway traffic. The audience was then addressed by Prof. Jozef Majerčak, Ph.D., the Head of the Department of Railway Traffic of the University of Žilina. Prof. Majerčak talked about the events in the area of research in railway traffic in the Slovak Republic with special emphasis on the projects developed by the Department.

The audience was then addressed by Ing. Jan Žačko, Deputy of Director General of the Slovak Railways who emphasised the importance of the education of railway professionals and then the good cooperation between the science and profession. After that the Conference attendees were addressed by Ing. Roman Vallovič, commercial director of ČD Cargo who described the role of the national operator on the liberalized market and stressed the importance of the necessary connection of the profession and science. The Head of the Agency for Regulation of Railway Traffic, Ing. Ján Bendžala stressed that the liberalized market should have an efficient and effective regulation, especially from the aspect of non-discriminated service provision in railway transport.

Then followed the invited lectures. The first lecturer was Assist.Prof. Borna Abramović, Ph.D. from the Faculty of Transport and Traffic Sciences University of Zagreb on the topic: Liberalisation of Railway Market as a Challenge for the National Operator presenting the foundations of the functioning of liberalization in the area of railway traffic and determining the position of the national railway operators on the liberalized market in the European Union. Next was the lecture given by Ing. David Krásenský on the topic: White Paper on European transport policy: What are the conditions and objectives in the context of changes in modal split in 2030 and 2050?. He briefly explained the main guidelines of the White Paper and reflected on the railway transport as part of the business, and which

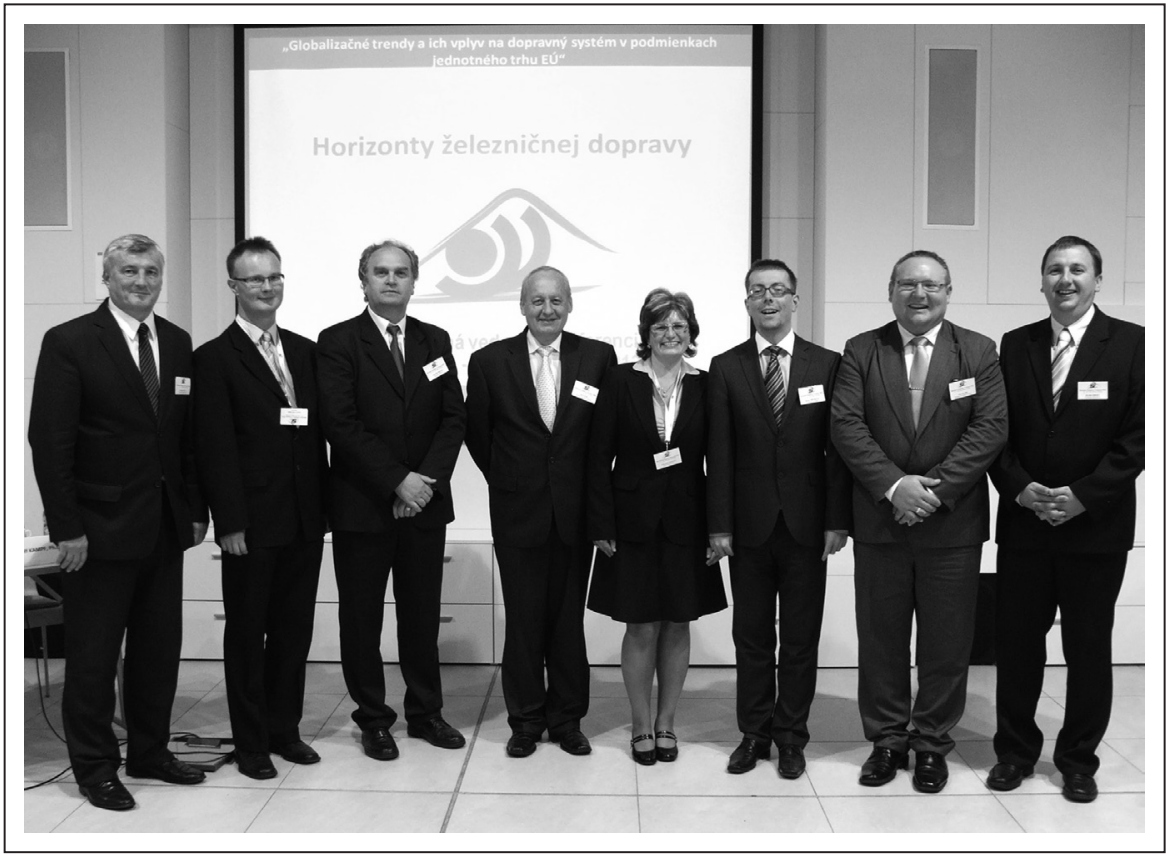

Conference Scientific Committee 
technical solutions can lead to efficient increase of modal split. This was followed by the lecture given by Ing. Matej Babin on the topic: Structure of the laws in force in the transport of dangerous goods. The lecture gave an overview of the regulations in the transport of dangerous materials and then made a comparative analysis of the regulations in Europe, North and South America, Asia, and Australia.

Then followed the lecturing sessions on the topics of: integrated passenger transport, applied psychology in railway traffic, railway infrastructure, and the development of railway traffic places in physical planning.

After the presented papers, a visit was organized to the shunting railway station Žilina Teplička which was officially opened to traffic on 1 June 2012.

Borna Abramović, Ph.D. Faculty of Transport and Traffic Sciences, University of Zagreb, Croatia 